\title{
Negara Berkembang vs Neoliberalisme
}

\author{
Oleh: Yusdani
}

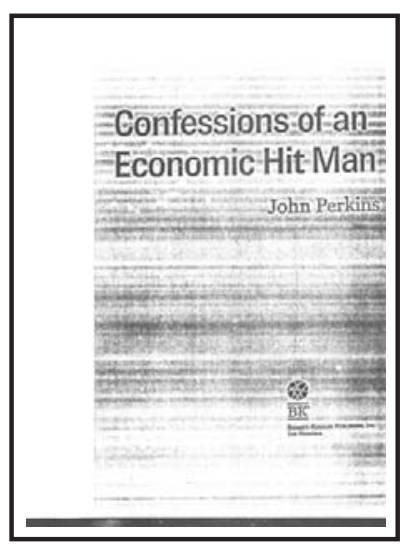
Judul : Confessions of an Economic Hit Man
Penulis : John Perkins
Penerbit : Berrett-Koehler Publishers, Inc.
ISBN : $1-57675-301-8$
Terbit : 2004
Tebal : 220 halaman +30 halaman Epilogue, John Perkins Personal History, Notes, Index, and About Author

\section{Pembukaan}

Fenomena gagalnya dominasi negara - ala Keynesian - dalam proses pembangunan dan kebijakan ekonomi pasca perang dunia $\mathrm{II},{ }^{1}$ telah mendorong negara-negara Barat seperti Amerika Serikat untuk merestrukturisasi dan

* Penulis adalah dosen tetap Program Studi Ekonomi Islam Fakultas Ilmu Agama Islam Universitas Islam Indonesia Yogyakarta. Email: yusdani_msi@yahoo.com.

${ }^{1}$ Sejak masa kehancuran Wall Street (dikenal dengan masa Depresi Hebat atau Great Depression) hingga awal 1970-an, wacana negeri industri maju masih 'dikuasai' wacana politik sosial demokrat dengan argumen kesejahteraan. Kaum elit politik dan pengusaha memegang teguh pemahaman bahwa salah satu bagian penting dari tugas pemerintah adalah menjamin kesejahteraan warga negara dari bayi sampai meninggal dunia. Rakyat berhak mendapat tempat tinggal layak, mendapatkan pendidikan, mendapatkan pengobatan, dan berhak mendapatkan fasilitas-fasilitas sosial lainnya. Dalam sebuah konferensi moneter dan keuangan internasional yang diselenggarakan oleh Perserikatan Bangsa Bangsa (PBB) di Bretton Woods pada 1944, setelah Perang Dunia II. Konferensi yang dikenal sebagai konferensi Bretton Woods ini bertujuan mencari solusi untuk mencegah terulangnya depresi ekonomi di masa sesudah perang. Negaranegara anggota PBB lebih condong pada konsep negara kesejahteraan sebagaimana digagas oleh John Maynard Keynes. Dalam konsep negara kesejahteraan, peranan negara dalam bidang ekonomi tidak dibatasi hanya sebagai pembuat peraturan, tetapi diperluas sehingga meliputi pula kewenangan untuk melakukan intervensi fiskal, khususnya untuk menggerakkan sektor riil dan menciptakan lapangan kerja. Pada kondisi dan suasana seperti ini, tulisan Hayek pada tahun 1944, The Road Of Serdom, yg menolak pasalpasal tentang kesejahteraan dinilai janggal. Tulisan Hayek ini menghubungkan antara pasal-pasal kesejahteraan dan kekalahan liberal, kekalahan kebebasan individualisme. http://id.wikipedia.org/wiki/Neoliberalisme accessed 25 Agustus 2008. 
mereformasi ulang posisi dan peran negara-negara berkembang terutama dalam bidang kebijakan ekonomi dan pembangunan. Salah satu kebijakan dimaksud adalah penerapan kebijakan pembangunan ekonomi ke arah liberalisasi yang lebih luas dan kepercayaan pada mekanisme pasar melalui serangkaian reformasi ekonomi berorientasi pasar. ${ }^{2}$

Kebijakan ekonomi yang dianggap gagal oleh negara-negara maju tersebut, sesunguhnya merupakan kebijakan berasal dari negara-negara maju juga yang mulai digulirkan sejak tahun 1950-an. Oleh karena itu, jika kebijakan kedua ini juga didorong oleh negara-negara maju untuk meliberalisasikan sektor ekonomi, tentu saja meminjam pendapat Antonio Gramsci bukanlah kosong dari kepentingan hegemonik Amerika Serikat berserta sekutunya. Tulisan ini ingin melihat seputar perubahan kebijakan tersebut, hingga mengkritisi bagaimana dampak buruknya ketika negara berkembang atau dunia ketiga berada di bawah rezim pasar. Narasi seputar dampak buruk ketiga negara-negara berkembang berada dalam cengkeraman rezim pasar atau neoliberalisme ${ }^{3}$ ini terungkap secara

${ }^{2}$ Muhadi Sugiono, 2006, Kritik Antonio Gramsci Terhadap Pembangunan Dunia Ketiga, (Yogyakarta: Pustaka Pelajar), hlm.8, pada tahun 1980-an, negara-negara berkembang di segala penjuru dunia mulai mengadopsi kebijakan-kebijakan yang bertujuan untuk merestrukturisasi watak peran negara dalam perekonomian, untuk meliberalisasi perdagangan domestik dan regulasi investasi serta untuk menswastakan seluruh perusahaan-perusahaan milik negara (BUMN). Dengan asumsi negara-negara berkembang dianggap gagal dalam mengelola kebijakan-kebijakan yang berorientasi pada pembangunan nasionalisme ekonomi. Oleh karenanya negara-negara Asia termasuk di dalamnya Indonesia dengan serta merta mengadopsi kebijakan-kebijakan tersebut untuk diterapkan sebagai langkah restrukturisasi Deni al Asy'ari, "Rezim Pasar Vs Kesejahteraan Sosial" http://72.14.235.104/search?q=cache: EXbmV-cytAkJ: www.imm.or.id/content/view $/ 189 / 191 /+$ john + perkin\&hl $=\mathrm{id} \& \mathrm{ct}=\mathrm{clnk} \& \mathrm{~cd}=7 \& \mathrm{gl}=\mathrm{i}$ d accessed 25 Agustus 2008

${ }^{3}$ Neoliberalisme itu istilah licin yang sering mengecoh pemakainya. Misalnya, ekonomi pasar dianggap identik neoliberalisme. Neoliberalisme memang melibatkan aplikasi ekonomi-pasar, tetapi tidak semua ekonomi-pasar bersifat neoliberal (ekonomi pasar sosial, bukan neoliberal). Atau, privatisasi sering dilihat identik dengan ciri kebijakan neoliberal. Padahal, tidak semua program privatisasi bersifat neoliberal. Mengapa istilah itu berawalan neo? Awalan neo (baru) pada istilah neoliberalisme menunjuk gejala kemiripan tata ekonomi 30 tahun terakhir dengan masa kejayaan liberalisme ekonomi di akhir abad ke-19 dan awal abad ke-20, yang ditandai dominasi financial capital dalam proses ekonomi. Namun, apa yang terjadi dalam 30 tahun terakhir bercorak lebih ekstrem daripada seabad lalu. Reinkarnasi liberalisme ekonomi akhir abad ke-19 dan awal abad ke-20 dalam bentuk lebih ekstrem itu berlangsung dengan mengakhiri era besar yang disebut embedded liberalism. Embedded liberalism merupakan model ekonomi setelah Perang Dunia II hingga akhir dekade 1970-an. Intinya, kinerja ekonomi pasar dikawal dengan seperangkat aturan yang membuat relasi antara modal dan tenaga-kerja tidak selalu berakhir dengan subordinasi labour pada capital. Seperti tata ekonomi seabad lalu, neoliberalisme berisi kecenderungan lepasnya kinerja modal dari 


\section{jelas dalam buku Confessions of an Economic Hit Man karya John Perkins. ${ }^{4}$}

kawalan, tetapi dalam bentuk lebih ekstrem. Dari hal kecil itu tampak, betapa sulitnya menunjuk persis arti neoliberalisme. Selain itu, neoliberalisme merupakan istilah yang lebih terpahami dalam konteks intelektual Eropa (istilah liberal punya arti lain di AS). Dalam perjalanan sejarah yang tumpang tindih, neoliberalisme banyak dikaitkan visi ekonomi kelompok seperti Mont Pelerin Society dan ekonom mazhab Chicago, seperti Milton Friedman, Gary Becker, dan George Stigler. Namun, neoliberalisme bukan sekadar ekonomi. Ia visi tentang manusia dan masyarakat, dengan cara pikir ekonomi yang khas sebagai perangkat utama. Mungkin dua lapis definisi yang saling terkait dapat membantu memahami jantung filsafat ekonomi neoliberalisme, B Herry-Priyono, "Neoliberalisme" Kompas (Opini) 15 Desember 2005, dan dapat juga diunduh melalui http://72.14.235.104/custom?q=cache: ezPEAi_8bc8J: www.kompas.com/kompascetak/0512/15/opini/2290496.htm + B.Herry-Priyono\&hl=en\&ct=clnk\&cd=2. Lebih lanjut dapat pula dibaca dalam http://id.wikipedia.org/wiki/Neoliberalisme.

${ }^{4}$ Buku Confessions of an Economic Hit Man karya John Perkins Penerbit: BerrettKoehler, 2004. Buku ini sudah diterjemahkan ke Indonesia oleh Herman Tirtaatmaja dan Dwi Karyani yang berjudul Pengakuan Seorang Ekonom Perusak diterbitkan oleh Abdi Tandur Jakarta tahun 2005. Dalam buku ini Perkins menceritakan perjuangan pribadinya dari seorang pelayan kerajaan menjadi pejuang yang gigih untuk hak asasi manusia dan orang-orang tertindas. Sebagai hasil rekuitmen terselubung oleh United States National Security Agency dan tercantum sebagai penerima gaji dari perusahaan konsulatan internasional, dia berkelana ke berbagai pelosok dunia - ke Indonesia, Panama, Ekuador, Kolumbia, Saudi Arabia, Iran dan negara strategis lainnya. Pekerjaannya adalah menerapkan kebijakan yang mempromosikan kepentingan korporatokrasi (Koalisi pemerintah, bank dan korporasi) Amerika Serikat, sambil menyatakan minat mengurangi kemiskinan - suatu kebijakan yang sebenarnya mengasingkan berbagai bangsa serta meyebabkan peristiwa 11 September dan meningkatkan Anti-Amerika. Isi buku ini secara garis besar terdiri atas 4 bagian meliputi 28 bab. Bagian I: $1963-1971$ menjelaskan bab1 Seorang Economic Hit Man Lahir, bab 2 "Untuk Seumur Hidupmu“.., bab 3 Indonesia: Pelajaran untuk Seorang EHM., bab 4 Menyelamatkan Sebuah Negara dari Komunisme.. bab 5 Menjual Jiwaku. Bagian II: 1971- 1975 mencakup bab 6 Peranku Sebagai Penyelidik., bab 7 Mengadili Peradaban., bab 8 Yesus, Dilihat Secara Berbeda., bab 9 Kesempatan Seumur Hidup. bab 10 Presiden dan Pahlawan Panama. bab 11 Perompak di Zona Terusan bab 12 Prajurit dan Pelacur. Bagian III; 1975 - 1981 meliputi bab 17 Negosiasi Terusan Panama dan Graham Green.. bab 18 Raja Diraja Iran. bab 19 Pengakuan Seorang Laki-Laki yang Dianiaya.., Bagian IV: 1981 - Sekarang berisi BAB 26 Kematian Presiden Ekuador.. bab 27 Panama: Kematian Presiden Lain, bab 28 Perusahaan Energiku, Enron dan George W. Bush.. Sebagai kelanjutan, dari Confession of the Economic Hit man (EHM), buku pertama Perkins yang cukup meledak baik di Indonesia, maupun di luar negeri adalah buku kedua judul aslinya, The Secret History of American Empire, adalah ulasannya tentang Indonesia pada bab-bab awal. Seperti diketahui, Indonesia adalah tempat tugas pertamanya selepas ia didaulat menjadi Bandit Ekonomi. "Indonesia adalah korban pertama saya", tulisnya. Hadirnya buku ini amat penting dan relevan bagi pembaca yang ingin mengetahui bagaimana negeri yang amat indah dan kaya ini dirusak oleh beragam elemen termasuk didalamnya Bandit Ekonomi. Bagaimana akhirnya negeri ini begitul seringnya menjadi langganan negara 
Dalam buku yang cukup menghebohkan dan kontroverial tersebut terkuak fakta intervensi negara-negra maju melalui lembaga-lembaga internasional yang dirancangnya dan melalui korporasi global merupakan strategi yang sudah diterapkannya sejak lama. Pengakuan Perkins, seorang professional yang bekerja untuk sebuah perusahaan multilateral Amerika Serikat, dalam buku, Confessions of an Economic Hit Man (EHM) ini, semakin menggambarkan bagaimana intervensi negara maju, terutama Amerika Serikat, melalui perusahaan transnasionalnya untuk mengeksploitasi dan menciptakan ketergantungan negaranegara berkembang pada Amerika Serikat. Dilukiskannya bagaimana peran EHM yang dibayar dengan gaji sangat tinggi untuk menjalankan misi yang disebutnya sebagai bagian dari faham corporatocracy ${ }^{5}$ :

"...They funnel money from the World Bank, the US Agency for International Development(USAID), and other foreign "aid" organizations into the coffers of huge corporations and the pockets of a few wealthy families who control the elections, payoffs, extortion, sex, and murder. They play a game as old as empire, but one that has taken on new and terrifying dimensions during

terkorup versi lembaga Transparansi Internasional selama beberapa tahun terakhir. Salah satu faktor yang mendorong Perkins menulis buku keduanya ini adalah adanya desakan dari para Bandit Ekonomi lainnya saat ia mempromosikan buku pertamanya tersebut. "Cobalah anda beberkan lebih detail segala yang terjadi di negara tempat anda bertugas, dan segala kerusakan akibat ulah orang-orang seperti kita yang (merusak) tapi mengatasnamakan kemajuan. Singkaplah imperium ini. Uraikanlah fakta-fakta dibalik tempat-tempat seperti Indonesia, tempat dengan data statistik bagus namun realitasnya sangat buruk", ujar salah satu Bandit Ekonomi. Lebih jauh buku ini juga menyibak keingintahuan publik mengenai siapa sesungguhnya penguasa dunia. Apakah AS yang diwakili Bush sebagai presiden, IMF atau lainnya yang dalam buku ini oleh Perkins disebut korporasi-korporasi jahat. Perkins menyebut para korporat jahatlah yang sesungguhnya menjadi penguasa dunia dan biang dari segala kerusakan di dunia. Pada halaman-halaman selanjutnya, Perkins menuturkan trik dan cara yang Bandit Ekonomi lakukan untuk menguasai dan mengendalikan negara-negara dunia ketiga. Bagi kita yang tinggal di Indonesia buku ini seolah mengajak kita flashback merekonstruksi serta memotret fragmen-fragmen hancurnya negeri ini. Buku kedua Perkins tersebut juga sudah diterjemahkan ke Indonesia oleh Wawan Eko Yulianto dan Meda Satrio yang berjudul Pengakuan Bandit Ekonomi Kelanjutan Kisah Petualangannya di Indonesia \& Negara Dunia Ketiga yang diberi pengantar oleh Budiarto Shambazy. Buku ini diterbitkan oleh Ufuk Press Jakarta tahun 2007.

${ }^{5}$ Korporatokrasi adalah sistem kekuasaan yang dikontrol oleh berbagai korporasi besar, bank-bank internasional dan pemerintah. Muhammad Amien Rais (2008). Agenda Mendesak Bangsa Selamatkan Indonesia (Yogyakarta: PPSK Press), hlm. 80, 81, 82 dan 219 Dalam bahasa Perkins adalah A word came to my mind: corporatocracy. I was not sure whether I had heard it before or had just invented it, but it seemed to describe perfectly the new elit who had made up their minds to attempt to rule the planet. John Perkins (2004). Confessions of an Economic Hit Man. (San Fransisco: Berret-Koehler), hlm 31 
this time of globalization". ${ }^{6}$

Menurut Perkins, ia diberi keleluasaan demi menciptakan ketergantungan dan mendapatkan kekayaan di Negara tempatnya bertugas. Hal ini juga terjadi ketika ia ditugaskan di Indonesia lewat perusahaan Chase T. Main Inc (MAIN) untuk pengembangan kelistrikan di Indonesia dan diberi "pengarahan" oleh seorang project managernya sebagai berikut:

"We all know how dependent our own country is on oil. Indonesia can be a powerful ally to us in tjhat regard. So, as you develop this master plan, please do everything, you can to make sure that the oil industry and all the others that serve it - ports, pipelines, construction companies - get whatever they are likely to need in the way of electricity for the entire duration of this twenty five year plan."

\section{Rezim Pasar}

Pilihan terhadap sistem pasar, ${ }^{8}$ adalah didasarkan pada asumsi mampu untuk mengatasi berbagai problem ekonomi yang terjadi di negara-negara yang

\footnotetext{
${ }^{6}$ John Perkins (2004). Confessions of an Economic Hit Man. (San Fransisco: BerretKoehler), hlm. ix.

${ }^{7} \mathrm{Ibid}, \mathrm{hlm} .25$.

${ }^{8}$ Globalisasi kapitalisme yang bertujuan untuk meminimalkan peran negara dengan menonjolkan peran swasta melalui sistem pasar pada mulanya bermaksud untuk memangkas sejumlah birokrasi negara dalam mengatur perdagangan dan investasi yang dinilai kurang "efesien" dan "efektif" dalam menjalankan tiga agenda utamanya yaitu, deregulasi, liberalisasi dan privatisasi. Negara pada saat itu bukan lagi dipahami sebagai solusi, akan tetapi justru negara dipahami sebagai problem keterbelakangan itu sendiri di negara-negara tersebut. Para kritisi menimpakan problem ekonomi kronis seperti inflasi dan rendahnya produktifitas yang menghadang negara-negara berkembang pada tahun 1970-an di pundak intervensi negara dalam perekonomian yang sangat kuat. Para kritisi di atas menilai peran negara telah mengakibatkan munculnya monopoli, menghalangi kompetisi dan menggiring pada inefesiensi sumber daya serta alokasinya yang tidak produktif semisal korupsi dan perburuan rente (rent seeking). Karena itu, negara-negara berkembang seperti Asia, Amerika Latin dan Afrika yang selama ini mengadopsi kombinasi berbagai kebijakan ekonomi yang beragam seperti nasionalisme ekonomi, intervensionisme komprehensif negara hingga sosialisme negara, untuk melakukan restrukturisasi dan reformasi posisi peran negara dalam kebijakan ekonomi dengan memberikan kewenangan dan keluasan bagi sistem pasar. Deni al Asy'ari, "Rezim Pasar Vs Kesejahteraan Sosial" http://72.14.235.104/search?q=cache: EXbmV-cytAkJ: www.imm.or.id / content $/$ view $/ 189 / 191 /+$ john + perkin\&hl=id\&ct $=$ clnk\&cd $=7 \&$ $\mathrm{gl}=\mathrm{id}$ accessed 25 Agustus 2008 dan Edy Suandi Hamid (2005). Globalisasi Ekonomi, Neoliberalisme, dan Perekonomian Indonesia. Pidato Pengukuhan dalam Jabatan Guru Besar pada Bidang Ilmu Ekonomi disampaikan di depan Sidang Senat Terbuka Universitas Islam Indonesia Yogyakarta 7 Mei 2005. hlm. 12-15.
} 
Yusdani: Negara Berkembang vs Neoliberalisme ...

dianggap terbelakang. Kepercayaan terhadap sistem pasar ini setidaknya mereka contohkan dengan keberhasilan negara-negara Asia Timur seperti Korea Selatan, Taiwan, Singapura, dan Malaysia tampil sebagai negara industri baru atau NICs (Newly Industrialist Countries) dengan menerapkan sistem ekonomi yang berbasis pada pasar. Walaupun pada akhirnya negara-negara yang disebut sebagai Newly Industrialist Countries ini menuai kegagalan, akibat dihantam oleh badai krisis ekonomi yang akar penyebabnya masih diselidiki hingga sekarang. ${ }^{9}$

Terlepas dari kegagalan negara-negara Asia Timur tersebut menerapkan sistem pasar, namun wacana yang dominan pada saat itu adalah kegagalan negara dalam mendorong kesejahteraan dan kemajuan bagi bangsanya. Oleh karena itu pada tahun 1970-an sangat kuat dorongan yang terjadi kepada negara-negara berkembang untuk menerapkan sistem ekonomi yang berbasis pada pasar, karena sistem ekonomi yang berbasis pada pasar dianggap mampu untuk menjawab krisis ekonomi dan mendukung bagi pertumbuhan ekonomi jangka panjang. ${ }^{10}$ Wacana restrukturisasi karakter dan peran negara yang berorientasi pasar menjadi sesuatu yang tidak tertandingi dengan wacana lain, tanpa mempedulikan watak dan lingkungan spesifik masyarakat atau negara tertentu. Walaupun akhirnya belakangan ini modus liberasi ekonomi yang didorong oleh negara-negara Barat tersebut diketahui bermuara terhadap pengikisan segala bentuk campur tangan negara dalam mengurus ekonomi (kesejahteraan) rakyat, dan menggantikannya dengan sistem pasar. ${ }^{11}$

Menurut Mansour Faqih bahwa landasan ideologis bagai rezim pasar adalah neoliberalisme dengan tujuan untuk menaklukkan peran negara di dunia ketiga seperti Indonesia. Oleh karenanya Mansour melihat kehadiran rezim pasar yang didorong melalui globalisasi ${ }^{12}$ ekonomi ini merupakan kelanjutan kolonialisme yang masih memiliki akar ideologis yang sama. Dengan demikian tawaran untuk keluar dari kemacetan ekonomi serta janji untuk meningkatkan pertumbuhan ekonomi negara-negara berkembang tidak lain hanyalah sebuah kedok baru dari imperialisme dan kolonialisme. ${ }^{13}$

Mekanisme rezim pasar tersebut diawali melalui penciptaan kebijakan free

${ }^{9}$ Mansour Faqih (2006). Runtubnya Teori Pembangunan dan Globalisasi. (Yogyakarta: Pustaka Pelajar), hlm.197-198.

${ }^{10}$ Muhadi Sugiono (2006). Kritik Antonio Gramsci Terhadap Pembangunan Dunia Ketiga. (Yogyakarta: Pustaka Pelajar), hlm.8.

${ }^{11}$ Deni al Asy'ari. “Rezim Pasar Vs Kesejahteraan Sosial” http://72.14.235.104/ search?q=cache: EXbmV-cytAkJ: www.imm.or.id/content/view/189/191/+john+per kin\&hl $=\mathrm{id} \& \mathrm{ct}=\mathrm{clnk} \& \mathrm{~cd}=7 \& \mathrm{gl}=\mathrm{id}$ accessed 25 Agustus 2008.

${ }^{12}$ Menurut Derrida, globalisasi tak lebih dari pada sebuah kelicikan retorik, yang ditujukan untuk menyembunyikan ketidakadilan Giovanna Borradori (2005). Filsafat dalam Masa Teror: Dialog dengan Jürgen Habermas dan Jacques Derrida. (Jakarta: Penerbit Buku Kompas), hlm. 33.

${ }^{13}$ Mansour Faqih (2006). Runtubnya Teori Pembangunan dan Globalisasi. (Yogyakarta: Pustaka Pelajar), hlm.197-198. 
trade yang merupakan hasil kesepakatan internasional yang telah ditandatangani pada bulan April 1994 di Marrakesh, Maroko, atau yang sering juga disebut dengan istilah General Agreement on Tariff and Trade (GATT). GATT ini merupakan suatu kumpulan aturan internasional yang mengatur prilaku perdagangan antar pemerintah. Selain itu GATT juga memiliki peran sebagai lembaga pengadilan untuk menyelesaikan sengketa perdagangan antar bangsa. Namun pada tahun 1995, GATT diambil alih perannya oleh organisasi pengawasan dan kontrol perdagangan dunia yang dikenal dengan sebutan World Trade Organizations (WTO). WTO sendiri diisi oleh lembaga perusahaan multinasional yang memiliki kepentingan dengan globalisasi ekonomi tersebut. Oleh karena itu, kebijakan-kebijakan yang keluar dari WTO tidak lain sebagai wujud dari suara TNCs ini. ${ }^{14}$

\section{Reformasi Kebijakan}

Reformasi kebijakan bagi negara-negara berkembang seperti Indonesia tentu saja sangat dibutuhkan bagi perusahan-perusahan transnasional tersebut. Sebab internasionalisasi produksi sebagai salah satu gejala globalisasi memerlukan kemudahan untuk relokasi industri sekaligus memberi kemudahan secara global. Cara yang lazim biasanya digunakan oleh lembaga keuangan internasional itu untuk menundukkan negara-negara berkembang sebagaimana pengakuan John Perkins salah seorang Economic Hit Man dalam bukunya Confession of an Economic Hit Man adalah dengan memberikan pinjaman utang yang sebanyakbanyaknya di luar batas kemampuan negara-negara berkembang tersebut untuk membayarnya. Sehingga ketika negara-negara berkembang terkendala untuk membayar utang tersebut, lembaga-lembaga internasional seperti IMF atau World Bank bisa memaksakan kehendaknya untuk mengatur berbagai kebijakan dalam negeri yang dapat menguntungkan peran TNCs atau proyek-proyek milik Amerika dan sekutunya. ${ }^{15}$

${ }^{14}$ Dengan berdirinya WTO ini, TNCs mengalami peningkatan jumlah maupun hasil penjualan yang jauh di atas negara. Misalnya pada tahun 1970 TNCs berjumlah 7000, namun pada tahun 1990, TNCs mengalami peningkatan hingga berjumlah 37.000. Tentu saja ini peningkatan yang luar biasa. Apalagi perkembangan TNCs tersebut juga diikuti dengan kemampuannya untuk menguasai $75 \%$ perdagangan dunia. Sehingga nilai penjualan mereka jika dibandingkan dengan PDB berbagai negara menghasilkan peringkat dimana 52 dari 100 terbesar adalah koorporasi, sedangkan negara hanya 48 lebihnya, dan Indonesia menduduki peringkat ke 31 dengan PDB lebih rendah dibandingkan angka penjualan lima koorporasi (Wall-Mart, General Motors, Exxon Mobile, Royal Dutch Shell, British Petroleum) pada tahun 2002. Edy Suandi Hamid (2005). Globalisasi Ekonomi, Neoliberalisme, dan Perekonomian Indonesia. Pidato Pengukuhan dalam Jabatan Guru Besar pada Bidang Ilmu Ekonomi disampaikan di depan Sidang Senat Terbuka Universitas Islam Indonesia Yogyakarta 7 Mei 2005, hlm.12-15.

${ }^{15}$ John Perkins (2004). Confessions of an Economic Hit Man. (San Fransisco: Berret- 
Yusdani: Negara Berkembang vs Neoliberalisme...

Menurut Perkins negara-negara seperti Amerika yang memegang kendali terhadap lembaga-lembaga keuangan internasional tersebut dapat memaksa negara-negara miskin - karena ketidaksanggupan mengembalikan utang - untuk menyerahkan sumber daya alamnya untuk dikelola oleh perusahaan-perusahaan negara-negara pemilik modal. Oleh karena itu tidak heran kemudian banyak aset-aset bangsa yang berupa BUMN (Badan Usaha Milik Negara) maupun aset dalam perut bumi seperti minyak, gas, emas, tembaga dan pasir diserahkan sepenuhnya kepada perusahan-perusahan Amerika. Seperti Freeport di Papua, Caltex di Riau, New Mon di Sulawesi, Exxon Mobile di Aceh dan Jawa Tengah Serta banyak yang lainnya. ${ }^{16}$

Tidak puas dengan hal itu, negara-negara pemegang rezim pasar pun bisa untuk mendesak negara-negara miskin untuk membuat suatu regulasi yang bisa memudahkan dan memberikan kenyamanan bagi perusahan-perusahan mereka beroperasi. Seperti halnya pembuatan Undang-Undang Penanaman Modal Asing (UU PMA) yang jauh dari keberpihakan terhadap rakyat Indonesia sendiri. Walaupun sebagian besar rakyat menolak atas pengesahan RUU PMA tersebut, namun pemerintah sebagai pengendali negara tidak mampu berbuat banyak akibat tekanan lembaga keuangan tersebut. Pada konteks inilah sebenarnya negara sudah kehilangan fungsinya. Karena peran-peran sosial banyak diambil alih oleh TNCs. Padahal sebagaimana diketahui, bagi rezim pasar ini, realitas sosial termasuk manusia hanya direduksi pada aspek ekonomi semata (homo Economicus). Manusia, alam, hutan dll merupakan aset yang bisa dikalkulasikan untuk mencapai laba. ${ }^{17}$

Dalam kondisi yang demikian, membiarkan kehidupan rakyat di tengah kekuatan rezim pasar sama saja artinya dengan meletakkan masa depan hidup manusia di mulut buaya yang suatu waktu siap untuk dilumat. Karena memang rezim pasar tidak ada sangkut pautnya dengan kesejahteraan rakyat ${ }^{18}$ ataupun keadilan sosial ${ }^{19}$ di negara-negara dunia ketiga, melainkan lebih didorong oleh motif kepentingan pertumbuhan dan akumulasi kapital berskala global. ${ }^{20}$

Koehler), hlm. 18-20.

${ }^{16} \mathrm{Ibid}, \mathrm{hlm} .24$.

${ }^{17}$ Deni al Asy'ari. “Rezim Pasar Vs Kesejahteraan Sosial” http://72.14.235.104/ search?q=cache: EXbmV-cytAkJ: www.imm.or.id/content/view/189/191/+john+per kin\&hl $=\mathrm{id} \& \mathrm{ct}=\mathrm{clnk} \& \mathrm{~cd}=7 \& \mathrm{gl}=\mathrm{id}$ accessed 25 Agustus 2008 .

${ }^{18}$ Untuk konsep Negara Sejahtera baca Darmawan Triwibowo dan Sugeng Bahagijo (2006). Mimpi Negara Kesejahteraan Peran Negara dalam Produksi Alokasi Kesejabteraan Sosial. Pengantar Siswono Yudo Husodo (Jakata: Pustaka LP3ES Indonesia).

${ }^{19}$ Muhadjir M. Darwin (2007). Revitalisasi NasionalismeMadani dan Penguatan Negara di Era Demokrasi. Pidato Pengukuhan Jabatan Guru Besar pada Fakultas Ilmu Sosial dan Ilmu Politik Universitas Gadjah Mada Yogyakarta, 11 April 2007, hlm.17.

${ }^{20}$ Deni al Asy'ari. “Rezim Pasar Vs Kesejahteraan Sosial” http://72.14.235.104/ search?q=cache: EXbmV-cytAkJ: www.imm.or.id/content/view/189/191/+john+per kin\&hl $=\mathrm{id} \& \mathrm{ct}=\mathrm{clnk} \& \mathrm{~cd}=7 \& \mathrm{gl}=\mathrm{id}$ accessed 25 Agustus 2008 . 


\section{Privatisasi dan Liberalisasi}

Program-program yang didesain oleh rezim pasar untuk dijalankan oleh negara dunia ketiga seperti privatisasi Aset Nasional, liberalisasi keuangan dan perdagangan, serta pencabutan subsidi untuk kesejahteraan sosial merupakan sebuah racun yang mematikan. Sebab tidak ada sebuah negara yang maju dengan membiarkan kehidupan rakyatnya di tengah gelombang rezim pasar. Bahkan kalau dikaji lebih jauh, Amerika, Inggris dan sebagian negara Eropa lainnya adalah negara-negara selalu melakukan proteksi bagi kehidupan rakyatnya, baik dalam sektor pertanian maupun dalam hal perdagangan. ${ }^{21}$

${ }^{21}$ Ibid. Amerika Serikat misalnya, yang selama ini selalu mempengaruhi kebijakannya melalui World Bank untuk menjauhi peran pemerintah di negara-negara berkembang terhadap regulasi pertanian rakyatnya, nyatanya Amerika sendiri merupakan negara yang sangat kuat dalam memproteksi sektor pertanian rakyatnya dengan memberikan subsidi produksi pertanian dan subsidi ekspor yang besar. Kebijakan ini bukanlah hal yang baru bagi AS, sebab sejak Abraham Lincoln mejabat sebagai presiden ke-16, pemerintah AS sudah mulai mentransfer tanah-tanah negara menjadi milik petani dengan ukuran perunit kapling 65 Hektar. Kemudian ketika berkembangnya sistem pembakaran mesin dan traktor, Di AS pengguna traktor meningkat pesat, dari 250.000 traktor pada tahun 1920 menjadi 2,3 juta pada tahun 1945. Bahkan AS adalah negara yang memberikan subsidi atas ekspor bagi rakyatnya. Bahkan kalau dirunut lebih jauh, AS adalah negara yang memiliki 100 lebih undang-undang dan peraturan disektor pertanian yang berpihak pada petani. Dan sejarah kemajuan AS dalam memproteksi pertanian ini juga diikuti oleh negara lainnya seperti Inggris, Jepang, Thailand dan Afrika. Hal yang juga dilakukan oleh pemerintahan Inggris, walaupun secara gagasan mereka menyambut baik Ide Adam Smith tentang Free Trade dan pencabutan proteksi negara terhadap pasar, namun pemerintahan Inggris tidak serta merta melaksanakannya, kenyataannya pemerintahan Inggris baru benar-benar meninggalkan Merkentelisme ini setelah 70 tahun dari tawaran tersebut, sebab pemerintahan Inggris sangat yakin, dengan dibukanya pasar bebas dan dicabutnya intervensi pemerintah terhadap sektor pertanian yang masih lemah, jelas akan menguntungkan pihak pemilik kapital dan alat-alat produksi, oleh karenanya pemerintahan Inggris memperkuat basis perekonomian dan pertanian rakyatnya. Baik dalam aspek pertanian maupun dalam aspek lainnya. Upaya yang dilakukan oleh Amerika dan Inggris tersebut juga dilakukan oleh pemerintahan Jepang, Setiawan.B dalam bukunya "Globalisasi Pertanian" (2003) menjelaskan bahwa setelah menyadari dampak buruk dari kebijakan Komodor Perry Amerika yang memaksa Jepang untuk membuka ekonominya bagi perdagangan luar negeri sekaligus dicabutnya proteksi pemerintah, membuat Jepang di bawah Dinasti Meiji bangkit dengan melakukan proteksi besar-besaran terhadap sektor perekonomian rakyat, bahkan selain sebagai regulator, pemerintahan Jepang juga terjun langsung sebagai entrepreneur (wiraswasta) di tengah tiadanya pengusaha swasta Jepang saat itu. Negara membangun dan mengoperasikan sendiri pelbagai perusahan, seperti batu bara, tembaga, tambang emas, baja, perkapalan, peremesinan, semen, kertas, gelas, kartun, dan banyak lainnya. Pemerintahan Jepang juga menerapkan pembatasan terhadap impor, Hambatan kuantitatif, diskriminasi, control devisa, dan tariff tinggi. Baca Khudari (2004). Neoliberalisme Menumpas Petani, 
Yusdani: Negara Berkembang vs Neoliberalisme ...

Jadi tampak dari sini bahwa kemajuan negara-negara seperti Amerika, Inggris dan sekutunya itu maupun di beberapa negara Asia bukan karena kehidupan rakyat diserahkan kepada mekanisme pasar, tetapi justru dicapai dengan campur tangan pemerintah/negara. Hal ini sesuai dengan kritik tajam yang dilontarkan oleh Karl Polanyi dalam bukunya "The Great Transformation" sebagaimana yang dikutip oleh Khudari, menurutnya "..dengan membiarkan mekanisme pasar menjadi satu-satunya direktur atas nasib umat manusia dan lingkungan alamnya, nantikanlah akan kehancurannya lingkungan alam dan masyarakatnya". Hal yang sama juga disampaikan oleh Noor Fauzi, bahwa liberalisasi pasar bagi petani, sama saja akan menghancurkan dan memusnahkan kehidupan para petani kita ke depan. ${ }^{22}$

Kalau beberapa Negara di Amerika Latin diamati, barangkali atas kejahatan rezim pasarlah yang membuat beberapa Negara seperti Venezuela, Kuba, Ekuador dan Brazil memberikan perlawanan atau arus yang berbeda terhadap kepentingan negara-negara adidaya tersebut. Misalnya bagaimana Hugo Cavez di Venezuela dan Evo Morales begitu gigihnya untuk melakukan nasionalisasi aset-aset mereka yang selama ini dipegang oleh rezim pasar. ${ }^{23}$

Kemudian sebagai contoh yang termashur adalah negeri Cina, yang selama ini dianggap sebagai Negara yang akan mengalami kegagalan karena tingginya proteksi Negara dalam perekonomian, ternyata secara diam-diam Cina menjadi bayang-bayang kekuatan ekonomi baru Asia yang secara perlahan-lahan mulai menggoyang kepentingan Amerika dan Negara-negara aktor kapitalis lainnya. Oleh karena itu, dengan adanya proteksi atau kedaulatan Negara untuk mengatur kehidupan rakyatnyalah jalan bagi kebangkitan sebuah Negara tersebut, begitu pula sebaliknya. ${ }^{24}$

\section{Penutup}

Dengan membaca buku Confessions of an Economic Hit Man dan The Secret History of American Empire karya John Perkins ini, terkuaklah hegemoni dan kepentingan neoliberalisme. Oleh karena itu, dengan belajar dari pengakuan jujur John Perkins tersebut, ada tiga resiko besar yang harus dihadapi oleh rakyat dalam sebuah negara yang sudah "dikudeta" oleh neoliberalisme, yaitu:

Pertama, karena neoliberalisme bertumpu pada persaingan atau kompetisi, bukan pada resolusi konflik. Hal ini terkait erat dengan peran negara sebagai

Menyingkap Kejahatan Industri Pangan. (Yogyakarta: Resist Book), hlm. 45-47.

${ }^{22}$ Fauzi, Noor, (2005). Memahami Gerakan-Gerakan Rakyat Dunia Ketiga. (Yogyakarta: Insist Press), hlm. 146.

${ }^{23}$ Deni al Asy'ari. “Rezim Pasar Vs Kesejahteraan Sosial” http://72.14.235.104/ search?q=cache: EXbmV-cytAkJ: www.imm.or.id/content/view/189/191/+john+per kin\&hl $=\mathrm{id} \& \mathrm{ct}=\mathrm{clnk \& cd}=7 \& \mathrm{gl}=\mathrm{id}$ accessed 25 Agustus 2008 .

${ }^{24}$ Ibid. 
mediator. Negara yang merupakan kontrak politik antar warga negara, melalui proses-proses politik yang disepakati bersama akan kehilangan fungsinya ketika rezim pasar melalui koorporasinya betul-betul mengkudeta negara. Sebab negaralah yang memiliki manajemen serta administrasi politik guna mengatur dan melayani kebutuhan dasar warga negara. Dalam kaitan ini jika peran negara untuk melayani dan menjalani hak-hak warga negaranya dihapus, sama artinya dengan masa ketika belum terbentuknya negara. ${ }^{25}$

Kedua, kepastian kehidupan manusia akan kehilangan pijakan. Para neoliberal yang memuja sistem pasar percaya bahwa hanya sistem pasar yang bebas (liberalisasi) yang bisa menggairahkan kehidupan ekonomi. Kepercayaan atau ketergantungan terhadap rezim pasar yang demikian akan membuat kehidupan rakyat menuai ketidakpastian, karena logika pasar hanya tergantung pada supply and demand.

Ketiga, penghapusan sejumlah aturan, sistem dan mekanisme negara yang menjadi alat untuk menjamin dalam bentuk subsidi terhadap masyarakat dipenuhi, dan pengalihan kepada pihak swasta. Jika hal ini terjadi rakyat akan kehilangan sandaran dan alat dalam bentuk sistem/mekanisme negara yang selama ini merupakan cara bagi negara untuk memenuhi tanggung jawabnya.Lebih

\footnotetext{
${ }^{25}$ Sebagai contoh dapat kita cermati bagaimana pilihan kebijakan yang diambil oleh pemerintah Indonesia ketika terjadi konflik antara masyarakat Porong Sidoarjo dengan Lapindo Brantas Inc akibat semburan lumpur panas Lapindo Inc yang membuat ribuan warga Porong Sidoarjo harus tergusur. Ternyata dalam kondisi ini negara yang memiliki kedaulatan tidak mampu mengambil peran strategis bagi rakyatnya, terbukti waktu satu tahun tidak ada langkah-langkah yang berpihak pada rakyat, rakyatnya nyatanya sampai sekarang masih banyak yang berada di penampungan sementara. Bahkan tuntutan rakyat agar PT.Lapindo Brantas untuk mencairkan uang ganti rugi secara cash tidak didukung oleh pemerintah. Menunggu sensistitifitas Lapindo untuk membantu rakyat tentu saja sesuatu yang amat musthail, karena korporasi bukanlah berjalan atas rasa belas kasihan, melainkan berjalan atas pertimbangan untung dan rugi. Persoalan kedua juga dapat kita amati dari peristiwa konflik warga dengan anggota Marinir AL yang terjadi di Alas Tlogo Pasuruan baru-baru ini. Demi kuasa bisnis, pihak Marinir sebagai tentara yang dibiayai oleh rakyat nyatanya dengan mudah untuk mengeluarkan semburan peluru mematikan untuk para ibu-ibu dan rakyat jelata yang berada disana. Sehingga warga pun harus kehilangan nyawa anak, orang tua atau tetangganya mereka hingga lima orang. Penembakan atau konflik yang terjadi tersebut tentunya bukan semata-mata karena tanah itu menjadi tempat latihan militer atau tanah itu milik rakyat, namun jauh dari itu sebenarnya juga akibat dari dominasi marinir untuk memberikan kuasa tanah tersebut pada korporasi. Sebab buktinya konflik terjadi ketika buldoser atau alat-alat berat untuk penggarapan proyek di tanah itu akan dilakukan. Namun upaya rakyat mempertahankan kedaulatannya harus berhadapan dengan kuasa pasar. Sekali lagi, negara dalam hal ini juga tidak sanggup membentingi rakyatnya dari kejahatan yang seperti demikian. Deni al Asy'ari, “Rezim Pasar Vs Kesejahteraan Sosial” http:/ 72.14.235.104/search?q=cache: EXbmV-cytAkJ: www.imm.or.id/content/view/189/191/+john+perkin\&hl=id\&ct=c $\operatorname{lnk\& cd}=7 \& g \mathrm{l}=\mathrm{id}$ accessed 25 Agustus 2008.
} 
Yusdani: Negara Berkembang vs Neoliberalisme ...

jauh lagi adalah tidak saja membuat jasa lebih mahal karena tidak ada subsidi negara, juga karena tidak ada mekanisme politik untuk pertanggungjawaban. ${ }^{26}$ Artinya peran swasta akan lebih didasari pada prinsip-prinsip pasar yang hanya menghitung untung dan rugi, tanpa beban tanggung jawab politis. Berbeda halnya dengan pelayanan yang diberikan oleh negara, selain murah, juga mengandung unsur pertanggung jawaban politik. ${ }^{27}$

Untuk itu, perlu untuk menumbuhkan, mengembangkan, menyebarkan berbagai wacana ancaman globalsiasi tersebut hingga mampu membentuk berbagai komunitas perlawanan sebagaimana yang sudah mulai berjalan di beberapa negara miskin. ${ }^{28}$ Dengan adanya kekuatan masyarakat sipil negaranegara yang sedang terjajah bisa tersadarkan kembali untuk menjadikan dirinya sebagai negara yang berdaulat. ${ }^{29}$

\section{DAFTAR PUSTAKA}

Abrahmasen, Rita (2004). Sudut Gelap Kemajuan, Relasi Kuasa Dalam Wacana Pembangunan. Yogyakarta: Lafadl Pustaka.

Asy'ari, Deni al. "Rezim Pasar Vs Kesejahteraan Sosial” http://72.14.235.104/ search?q=cache: EXbmV-cytAkJ: www.imm.or.id/content/view/189/191/ +john+perkin\&hl=id\&ct=clnk\&cd=7\&gl=id accessed 25 Agustus 2008.

Borradori, Giovanna (2005). Filsafat dalam Masa Teror: Dialog dengan Jürgen Habermas dan Jacques Derrida. Jakarta: Penerbit Buku Kompas.

Darwin, Muhadjir M. (2007). Revitalisasi NasionalismeMadani dan Penguatan Negara di Era Demokrasi. Pidato Pengukuhan Jabatan Guru Besar pada Fakul;tas Ilmu Sosial dan Ilmu Politik Universitas Gadjah Mada Yogyakarta, 11 April 2007.

${ }^{26}$ Agus Surata dan Tuhana Taufiq A. (2002). Runtubnya Negara Bangsa (Yogyakarta: UPN Veteran), hlm.191 dst. baca juga Kenichi Ohmae (2002). Hancurnya Negara-Bangsa Bangkitnya Negara Kawasan dan Geliat Ekonomi Regional di Dunia Tak Berbatas, terj.Ruslani dari Judul Asli: The End of the Nation State: The Rise of Regional Economics. (Yogyakarta: Penerbit Qalam), hlm. 1-36. dan N.B. Susilo (2006). Indonesia Bubar. (Yogyakarta: Pinus Book Publisher), hlm. 51-52.

${ }^{27}$ Deni al Asy'ari. "Rezim Pasar Vs Kesejahteraan Sosial” http://72.14.235.104/ search?q=cache: EXbmV-cytAkJ: www.imm.or.id/content/view/189/191/+john+per kin\&hl $=\mathrm{id} \& \mathrm{ct}=\mathrm{clnk \& cd}=7 \& \mathrm{gl}=\mathrm{id}$ accessed 25 Agustus 2008

${ }^{28}$ Salah satu contoh baca Baskara T. Wardaya (2008). Indonesia Melawan Amerika Konflik Perang Dingin 1953-1963. (Yogyakarta: Galang Press).

${ }^{29}$ Edy Suandi Hamid (2005). Globalisasi Ekonomi, Neoliberalisme, dan Perekonomian Indonesia. Pidato Pengukuhan dalam Jabatan Guru Besar pada Bidang Ilmu Ekonomi disampaikan di depan Sidang Senat Terbuka Universitas Islam Indonesia Yogyakarta 7 Mei 2005.hlm.4-7, dan Deni al Asy'ari, "Rezim Pasar Vs Kesejahteraan Sosial" http://72.14.235.104/search?q=cache: EXbmV-cytAkJ: www.imm.or.id/content/view $/ 189 / 191 /+$ john + perkin\&hl=id\&ct $=\operatorname{clnk\& cd=7\& gl=id}$ accessed 25 Agustus 2008 . 
Yusdani: Negara Berkembang vs Neoliberalisme ...

Faqih, Mansour (2002). Jalan Lain, Manifesto Intelektual Organik. Yogyakarta: Insist Press.

Faqih, Mansour (2006). Runtuhnya Teori Pembangunan dan Globalisas. Yogyakarta: Pustaka Pelajar.

Fauzi, Noor (2005). Memahami Gerakan-Gerakan Rakyat Dunia Ketiga. Yogyakarta: Insist Press.

Hamid, Edy Suandi (2005). Globalisasi Ekonomi, Neoliberalisme, dan Perekonomian Indonesia. Pidato Pengukuhan dalam Jabatan Guru Besar pada Bidang Ilmu Ekonomi disampaikan di depan Sidang Senat Terbuka Universitas Islam Indonesia Yogyakarta 7 Mei 2005.

http://id.wikipedia.org/wiki/Neoliberalisme accessed 25 Agustus 2008.

Jurnal Seri Gerakan Sosial (2003). Gelombang Perlawanan Rakyat; Kasus-Kasus Gerakan Sosial di Indonesia. Yogyakarta: Insist Press.

Khudari (2004). Neoliberalisme Menumpas Petani, Menyingkap Kejahatan Industri Pangan. Yogyakarta: Resist Book.

Nugroho, Heru (2001). Negara, Pasar dan Keadilan Sosial. Yogyakarta: Pustaka Pelajar.

Ohmae, Kenichi (2002). Hancurnya Negara-Bangsa Bangkitnya Negara Kawasan dan Geliat Ekonomi Regional di Dunia Tak Berbatas, terj.Ruslani dari Judul Asli: The End of the Nation State: The Rise of Regional Economics. Yogyakarta: Penerbit Qalam.

Perkins, John (2004). Confessions of an Economic Hit Man. San Fransisco: BerrettKoehler. Edisi Indonesia adalah Perkins, John (2005). Confessions of an Economic Hit Man. Jakarta: Abdi Tandur.

Perkins, John (2007). The Secret History of American Empire diterjemahkan ke Indonesia oleh Wawan Eko Yulianto dan Meda Satrio yang berjudul Pengakuan Bandit Ekonomi Kelanjutan Kisah Petualangannya di Indonesia \& Negara Dunia Ketiga yang diberi pengantar oleh Budiarto Shambazy. Jakarta: Ufuk Press .

Priyono, B Herry- "Neoliberalisme" Kompas (Opini) 15 Desember 2005, dan dapat juga diunduh melalui http://72.14.235.104/custom?q=cache: ezPEAi_8bc8J: www.kompas.com/kompas- cetak/0512/15/opini/2290496. $\mathrm{htm}+\mathrm{B}$. Herry-Priyono\&hl=en\&ct=clnk\&cd=2.

Rais, Muhammad Amien (2008). Agenda Mendesak Bangsa Selamatkan Indonesia. Yogyakarta: PPSK Press.

Seabrook, Jeremy (2006). Kemiskinan Global Kegagalan Model Ekonomi Neoliberalisme. Yogyakarta: Resist Book.

Stiglitz, Joseph E. (2003). Globalisasi dan Kegagalan Lembaga-Lembaga Keuangan Internasional. Jakarta: Ina Publikatama.

Sugiono, Muhadi (2006). Kritik Antonio Gramsci Terhadap Pembangunan Dunia Ketiga. Yogyakarta: Pustaka Pelajar. 
Yusdani: Negara Berkembang vs Neoliberalisme ...

Surata, Agus dan Tuhana Taufiq A. (2002). Runtuhnya Negara Bangsa. Yogyakarta: UPN Veteran.

Susilo, N.B (2006). Indonesia Bubar. Yogyakarta: Pinus Book Publisher.

Triwibowo, Darmawan dan Sugeng Bahagijo (2006). Mimpi Negara Kesejahteraan Peran Negara dalam Produksi Alokasi Kesejahteraan Sosial. Pengantar Siswono Yudo Husodo. Jakata: Pustaka LP3ES Indonesia.

Wardaya, Baskara T. (2008). Indonesia Melawan Amerika Konflik Perang Dingin 1953-1963. Yogyakarta: Galang Press. 